\title{
İlk Şehirler ve Yazılı Medeniyete Geçiş
}

Öz

Yazı ilk defa MÖ 4000 yılının sonlarında Mezopotamya'da ortaya çıkmıștır. Resim yazısı ile başlamış zamanla ideografik yazı şeklini almışıı. İlk olarak çivi yazısı sistemi ile ve Sümerce olarak başlamıştır. İnsanoğlu kentleri kurmadan önce Neolitik Dönem ile yerleşik hayata geçmiştir. Güneydoğu Toroslar'ın eteklerinde, ilk köy yerleşimleri kurulmuştur. Ardından ilk kentler MÖ 4000'li yılların sonlarına doğru Güney Mezopotamya'da ortaya çıkmıştır. Sümerler tarafından kurulduğu kabul edilen ilk kentler, aynı zamanda siyasal olarak birer kent devletiydi. Site adı verilen bu kent devletlerine Ur, Uruk, Eridu, Lagaş, Kiş ve Larsa gibi devletleri örnek verebiliriz. Harran, Babil, Kudüs ilk büyük kent örneklerini oluşturur. Mezopotamya'da hukuk ve kanun yazma geleneği Sümerler ile başlamıştır. Bu gelenek ve kanun yazma tekniği zamanla Mezopotamya'da yaşamış olan tüm toplumları etkilemiştir. Urukagina Kanunları, bilinen ilk Sümerce hukuk metnidir. Hammurabi yasaları ise MÖ 1760 yılında Mezopotamya'da ortaya çıkan tarihin en eski ve en iyi bir şekilde korunmuş yazılı kanunları arasındadır. Bu dönemden önce ortaya çıkan yasa koleksiyonları arasında Ur kralı Ur-Namnu'nun kanun kitabı (MÖ 2050), Eşnunna tarafından oluşturulan kanun kitabı (MÖ 1930) ve İsin'li Lipit-Iştar'ın kanun kitabı (MÖ 1870) bulunmaktadır. Yazının bulunması uygarlığın, bugün geldiği noktaya ulaşmasında atılıış en önemli adımdır.

Anahtar kelimeler: Eridu, Yazı, Ur, Kudüs, Babil, Urugakina.

\section{First Cities and Passing to Writing Culture}

\begin{abstract}
Writing firstly exists in Mesopotamia at the end of the year 400 B.C. Writing firstly began with hieroglyph in Sumers. It began with picture writing and then changed to ideographic writing. Before building the cities, human beings firstly settled down in Neolytic era. In the valley of the southeastern Toros mountains, they setteler the first villages. After that, the first cities exist in southern Mesopotamia at the end of the 4000 B.C. The first cities which were accepted that Sumers founded were politically city states at the same time. We can give Ur, Uruk, Eridu, Lagoes, Kis and Larsa cities as an example to these city states which were called sites. Harran, Babil and Jerussalem are first big city samples. Judgement and law writing tradition firstly began with Sumers. These judgement and law writings affected all the societies lived in Mesopotamia by the time. Urukagina laws were the first known law writing materials. Hammurabi laws were amongst the ol dest and well protected laws which exist in Mesopotamia in 1760 B.C. Among the law collections before this era, the law book of Ur king Ur Namnu (2050 B.C.), Eşnunna law book (1930 B.C) and the law book of Lipit Isstar from Isin can be counted.The invention of the writing is the most important step to reach the culture to the level of our Era.
\end{abstract}

Keywords: Eridu, Writing, Ur, Jerussalem, Babil, Urugakina 


\section{İlk Şehirler ve Yazılı Medeniyete Geçiş}

Düşüncelerin herhangi bir yüzey üzerinde tespiti demek olan yazı, tarih içinde birçok aşamalar geçirmiş ve bugünkü kullanımına ulaşmıştır (Kınal, 1963: 1). Yazı, uygarlık tarihi açısından çok önemli bir kültürel faktördür ki bu özelliğiyle tarih onunla başlamaktadır. Paleolitik Devir' de avcı ve toplayıcı bir yaşam şekliyle mağaralarda yaşayan insanlar daha iyi avlar bulabilmek için ve av sahnelerini göstermek amaçlı duvar resimleri çizmişlerdir. Yine bu mağara resimlerinde av hayvanlarının bol olduğu bölgeler ile bu bölgelerde hangi cins hayvanların olduğunu gösteren mağara resimlerine de rastlanmıştır (Kınal, 1963: 1; Chiera 1938: 49). Günümüzde yapılan kapsamlı araştırmaların sonucunda çoğu yazı türünün resim yazısından doğduğu anlaşıllmış ve yazının Üst Paleolitik devirlerin duvar sanatında başladığı ileri sürülmüştür.

Uygarlık tarihinde önemli bir yer tutan ve tarihsel devirlerin oluşmasını sağlayan yazı, ilk defa MÖ 3200 yılında Mezopotamya ve Mısır'da ortaya çımıştır. Yazının ilk olarak kullanıldığı Önasya'nın eski medeniyetleri üzerine sahip olduğumuz bilgilerimiz, 19. yüzyılın başlarına kadar Tevrat'nn veya eski Yunan yazarlarının anlattıkları bilgilerden oluşmaktaydı. Bunlardan Herodotos ve Ksenophon gördükleri, gezdikleri memleketleri, eserlerinde anlatıyorlardı. Hâlbuki bu, eski Önasya kavimleri MÖ 3000. yıldan itibaren kendilerine dair tarih bilgilerini kendi yazıları ile yazmışlardı (Kınal, 1963: 2).

İnsanlık tarihinin en önemli buluşu olan yazı, çivi yazısı sistemi ile başlamıştır. Sümerler tarafindan icat edilen ve bugüne kadar çıkarılan eski tabletlerin çoğundan elde edindiğimiz sonuç, bu çivi yazılı metinlerin MÖ 3200 yılına tarihlenebilir ve Sümer dilinde yazılmış olmasıdır. Sümer çivi yazısını Sümer topraklarına yakın milletler de kullanmıştır. MÖ 2000 yılında Yakındoğu'da çokça kullanılan bir yazı olmuştur (Kramer, 2002: 309).

Yazı, yumuşak kil üzerine sivriltilmiş uçlu kamış parçaları ile şekiller çizilerek gerçekleştirilmiş̧ir. Kullanılan kil tabletin kızgın firınlarda pişirilmesi ile ise kalıcı yazı elde edilmiştir (Köroğlu, 2006,53).

Çivi yazısı, resim yazısı olarak başlamış ve her işaret bir nesnenin resmi, aynı zamanda o nesnenin ismine yakın veya aynı olan kelimeyi de anlatıyordu. Bu sistemde iki zorluk vardı. İşaretlerin şekli ve çokluğu çabuk okumayı zorlaştırıyordu. Sümer yazarları bu birinci zorluğu işaretlerin resim yazısı hâli yok oluncaya kadar basitleştirmekle çözümlemişler, ikincisini de işaretlerin miktarlarını azaltıp onların ne 
olduğunu belirten yardımcı işaret kullanmışlardır. Çok önemli işaretlerin ideografik değeri yerine fonetik değerini kullanmışlardır (Kramer, 2002: 309; Köroğlu, 2006: 54).

İnsanların yazıyı öğrenmesi uzun süren bir aşama ile olmuştur. Önce mağara duvarlarına, kaya ve taşlara yaşadıkları olayları anlatan resimler yapılarak başlamıştır. Ancak bu resimler tam anlamıyla birer yazı niteliği taşımamaktaydı. Zamanla bu resimlerin gelişmesiyle ideografik yazı şekli ortaya çıkmıştır.

Uygarlıkların kendilerini barbarlıktan ayırt eden özgün başarıları, kuşkusuz yazının ortaya çıkışı ile başlamaktadır. Sümer, Mısır ve Hindistan'da ekonomi, sayı işaretleme, ağırlık ve uzunluk ölçme ve zaman hesaplama sistemleri yazının icadı ile mümkün olmuştur. $\mathrm{Bu}$ sayede bilgi biriktirme ile var olan bilgiler kuşaktan kuşağa aktarılmış (Çı̆̆, 1994: 685) ve bu aktarılan bilgiler de yeni tür bilimlerin ortaya çıkmasına olanak sağlamıştır (Childe, 2009: 147).

Tarihte insanlığın son beş bin yılda dünyanın başka yerlerinde elde ettiği muvaffakiyetlerinin son derece az ve noksan bir kaydı vardır. Tarihin incelediği kesim, insanların dünyada etkin olmaya başladıklarından bu zaman kadar olan bölümün olsa olsa yüzde biri kadardır (Childe, 1996: 19). Anlaşılacağı üzere yazının ortaya çıkışı ve gelişimi ile büyük kentler (şehirler) kurulmuştur. Fakat bir de yazının icadından önce var olan kent oluşumu hakkında açıklayıcı bilgiler vermek yerinde olacaktır.

İnsanoğlu kentleri henüz kurmadan önce, MÖ 10.000'li y1llarda Neolitik Dönem ile birlikte, ilk kez yerleşik hayata geçmiştir. Bu dönemde "Bereketli Hilal" adı verilen Anadolu'nun Güneydoğu Toroslar'ın eteklerinde, ilk köy yerleşimlerinin kurulduğunu görüyoruz. Diyarbakır/Çayönü ve Körtik Tepe, Batman’da Hallan Çemi, Urfa’da Nevali Çöri ile Göbekli Tepe gibi ilk köy yerleşmeleri, insanlığın toprağa yerleştiği ve üretici bir pozisyona doğru geçtiği bu dönemde kurulmuştur. Bu Neolitik yerleşmeler, kentlerin ortaya çıkışının ilk öncülleri olmuştur. İkinci öncülü ise Orta Anadolu'da MÖ 7000'li yıllarda kurulan Konya-Çatalhöyük ile Kuzey Irak’ta kurulan Jarmo yerleşmeleridir. Araştırmacılara göre nüfusu 10 bin civarında olan Çatalhöyük, artık köy diyebileceğimiz bir yerleşimin özelliklerini çoktan aşmıştır. Çatalhöyük’teki bu yapı, kentlerin ortaya çıkışının habercisi olmuştur (Kuhrt, 2009: 17-19). Bu iki öncülün ardından ilk kentler, MÖ 4000'li yılların sonlarına doğru Güney Mezopotamya'da ortaya çıkmaya başlamıştır. Sümerlerce kurulduğu kabul edilen etrafı surlarla çevrili ve bir tapınak etrafında diğer yapıların yer alması ile şekillenen ilk kentler, aynı zamanda siyasal olarak birer kent devletiydi. Site adı verilen bu kent devletlerine Ur, Uruk, Eridu, Lagaş, Kiş ve Larsa gibi devletleri örnek verebiliriz (Kuhrt, 2009: 23-34). 
Bilim adamlarının çoğu ilk kentlerin MÖ 4750 yılında Mezopotamya'da görüldüğü konusunda fikir birliği içindedir. Mezopotamya'da ortaya çıkan bu gelişme, kısa bir süre sonra benzer bir şekilde Mısır'da da ortaya çıkacaktır. Bu iki bölgede kentlerin benzer bir şekilde ortaya çıkmasında coğrafi olarak Mısır'da Nil Nehri'nin, Mezopotamya'da ise Firat ve Dicle nehirlerinin varlığı etkili olmuştur.

MÖ 4000 yılından sonra Yakındoğu'da madenleri tanımaya başlayan Neolitik toplumları, MÖ 3500'lerde ise tuncu keşfetmişlerdi. Tuncun iş bölümü ve uzmanlaşma gerektiren bir üretim aşamasına sahip olması tarım dışında faaliyetlerle uğraşan bir nüfus ortaya çıkarmıştır.

MÖ 3000. yılın başlarında Mısır, Mezopotamya ve İndus Vadisi'nde örgütlenme açısından basit çiftçilerden oluşan küçük toplumların yerine çeşitli meslek ve sınıfları içeren devletler görülmekteydi. Bu dönemde sadece kulübe ve çiftlik evleri değil anıt mezarlar, tapınaklar ve sarayların çoğaldığını da görmekteyiz. Ayrıca artan gelirlerin muhasebesini tutmak da güçleştiği için rahip yöneticiler, yeni yazı ve rakam düzenekleri geliştirmek zorunda kalmışlardır. Tanrı adına toplanan gelirlerle, tapınaklar sadece dinsel yasam merkezi olarak değil, aynı zamanda sermaye birikiminin de çekirdeğini oluşturmuştur. Artık, ticaret ilişkileri de oldukça ilerlemiş, kentlerin pazarladıkları ürünler çeşitlenmiştir. Sonuç olarak da kendine yeterli besin üretimine (tarım devrimi) ve dış ticarete dayalı ekonomiye dönüşüm, büyük bir nüfus artısına yol açmış ve ikinci devrim yani "kentsel devrim”" gerçekleşmiştir (Child, 1996: 104-112).

Tarım, kentlerin beslenmelerini desteklemek için çok büyük öneme sahip olduğundan kent yerleşmeleri ilk önce tarım ekonomisinin yoğun olduğu bu yerlerde meydana gelmişti. İlk kentlerin ortaya çıkışı ile ilgili çalışmalar yapan Gordon Childe, kentsel devrim dediği yaklaşımında, kentlerin toplumdaki organik dayanışmanın bir sonucu olarak ortaya çıktığını belirtmiştir ( Huot-Valbella-Tahlmann, 2000: 42; Child, 1996: 104-108).

Tarım alanlarının sulanması sonucu elde edilen artı ürün ve bu artı ürünü korumak için kentlerin etrafının surlarla çevrilmesi, surların kentlerin etrafına çevrilme iradesini ortaya koyan bir örgütsel yapının olduğunu görmekteyiz. Dinsel kurum ile toplumu mukaddes değerler çevresinde birleştirerek bu yapının işleyişini kolaylaştırmak ve artı ürünün yıl boyunca tüketilememesi gerçeği karşısında çevre kentlerle başlayan ticari ilişkilerde daha etkili olan kentlerin büyüyüp gelişerek siyaseten bölgesel güç hâline gelmeleri kaçınılmaz olmuştur. Doğan ihtiyaçların sonucu olarak yazı; silindir mühür ve hukukun ortaya çıkması ile toplumda yönetici, din adamı, asker, tüccar, 
zanaatkâr ve çiftçi gibi toplumsal sınıfların oluşmaya başlaması kentlerin oluşum sürecindeki gelişmeleri özetler niteliktedir.

Kentlerin meydana gelişinde tarımın kabullenilmesinden daha öte bir şeye gereksinim duyulmuştur. Çünkü birçok tarımsal bölgede kentler gelişmemiştir. Kentlerin ortaya çıkışı için temel şart, bir uygarlığın mevcudiyetidir. Kent ve uygarlık kelime olarak aynı kökten gelmektedir ve bunlar arasındaki münasebet tarihsel olarak önemli bir kanıt oluşturmaktadır.

İlk kentlerin oluşumuna ilişkin yukarıda kısaca özetlediğimiz süreç, aslına bakılırsa bir anda olup biten bir gelişme değildir. Bu süreç, binlerce yıldır değişim ve dönüşüm geçirerek günümüze kadar gelmiştir. Günümüzde kentler, özellikleri itibariyle endüstri kentleri, metropol kentler ve küresel kentler gibi çeşitleriyle, bu değişim ve dönüşümü yaşamaya devam etmektedir.

\section{Uruk (Tel El-Varka) Dönemi (Mö 4000-3100)}

Akrabalık-aşiret bağlarına dayanan bir toplumdan bölgesel siyasi örgütlenmiş bir topluma geçiş ile kentlerin temelleri bu dönemde atılmaya başlanmıştır. Burada kent kavramının kriterlerini de vermemiz yerinde olacaktır. Kent kavramı altında etnik köken, ırk ve kültür bakımından aynı yapıya sahip fertlerden oluşan, karmaşık bir teknoloji ve iş bölümüne dayanan bir ekonomik sistemi olan, nüfusu çoğalmış, kamusal bir yönetim barındıran yerleşme şeklinde tanımlanmaktadır. Yine kentleşme, toplum bünyesinde genişleyerek artan oranda örgütsellik, işbölümü ve uzmanlaşma meydana getirmektedir. İnsan ilişkilerinde farklılıklara neden olan nüfus birikimi süreci olarak da tanımlanmaktadır (Keleş, 1993). Ekonominin kentleşmede özel bir önemi vardır. Bu nedenle kentleşme tarif edilirken tarımsal üretimden daha yukarıda bir üretim seviyesine geçiş olarak da tanımlanabilir. Bu geçiş bütün üretim denetleme fonksiyonlarının kentlerde bir araya gelmesini zaruri kıldığ 1 gibi, kentlerin daha da büyümesine ve yoğunluk kazanmasına, heterojenlik ve bütünleşme seviyelerinin fazlalaşmasına yol açmıştır. Kent kriterlerini özetle şöylece sıralayabiliriz: İnsanların bir arada yaşaması, kurumsallaşma ve teşkilatlanmanın olması. Ailelerin ihtiyacı olan maddeleri birimlerinde karşılamadan başkalarının ürettiği ürünlerden sağlaması. İhtiyacın dışında ürün üretilmesi ile bu ürünlerin ticaretinin yapılması. Merkez ve taşra arasında köprü görevi yapması. Taşra ve merkezde üretilen ürünlerin toplanması ve dağıtımının yapılması. Dinî, idari, ekonomi ile ilgili kurumları bünyesinde bulundurması. Coğrafi olarak geniş bir bölgenin merkezi konumunda olması. Uzak bölgeler ile ticaret yapılması ve hiyerarşik sisteminin olması (Mieroop, 2006: 40-48; Kuhrt, 2009: 28-33). 
Ubaid Dönemi ile başlayan kentleşme süreci, Uruk Dönemi’nde gelişme göstermişti. Yerleşmelerin genişliği ve sayıları artmıştı. Bu durum özellikle Orta ve Aşağ1 Mezopotamya'da görülmekteydi fakat Orta Mezopotamya'daki kent nüfusunun artışı yavaş ve doğal iken Uruk’taki artış muazzamdı (Köroğlu, 2006: 46-48).

Uruk, bu dönemde etrafinda daha küçük yerleşimlerinin bulunduğu bölgesel bir merkez hâline gelmişti ve gerçek anlamda Mezopotamya'nın (insanlık tarihinde) ilk kenti denilebilirdi.

Kent oluşumunun Uruk’ta ortaya çıkması şüphesiz ki bulunduğu bölgede farklı ekolojik alanların oluşu ve verimli topraklarda yer almasıydı. Bölgede yapılan tarım, kanallardan gelen sulama ile gerçekleşmekteydi. Kanalların suyu Fırat'ın kol/kollarından temin edilmekteydi. Verimli topraklar yoğun tahıl üretimini desteklemekte ve aynı zamanda meyve bahçeleri de çoğunluktaydı. Hurma bahçelerinin önemi büyüktü. Sulanan araziler arasında ise bozkırlar bulunmakta ve buralar koyun ve keçi gibi hayvanlara otlak görevi yapmaktaydı. Ayrıca bu alanlarda yine avcılık da yapılabilmekteydi. Bataklık bölgede ise kuş ve balık avı yapılır ve manda sürüleri güdülürdü. Tüm bunlar ürün çeşitliliğine ve üreticiler arasında farklılaşmaya neden olmuş ve sınıflar (çobanlar, balıkçılar, çiftçiler, bahçeciler, avcılar) ortaya çıkmaya başlamıştır (Nissen, 2004: 51). Bu gelişmeler yeni teknolojilerin ortaya çıkmasına da sebep olmuştur. Örneğin; saban, tarımın yoğun bir şekilde yapılmasına izin vermiştir. Yoğun tarım ise artı ürüne dönüşmüş ve değiş-tokuş ile yapılan alışveriş kentleşmedeki en önemli faktörü de oluşturmuştur. Uruk nüfusunun çoğunluğu çiftçiydiler. Geri kalanı ise tarım dişı uğraşlara yönelmişlerdi. Bu dönemde birçok iş grubu ortaya çıkmaya başlamıştı (Köroğlu, 2006: 49-52). Bunlar;

- Dokumacilar (kadınlar)

- $\quad$ Maden ergitme atölyeleri

- $\quad$ Silindir mühür ustaları

- Anıt, kabartma/rölyef ve heykelcilikte ustalık gerektiren eserler.

- Çanak-çömlek, konik (devrik ağızlı) kenarlı kâseler, bunlar kalıpta, standart boyutlarda şekillendirilmişlerdi. Ön Asya'nın neredeyse her tarafına dağılmıştı. (Mieroop, 2006: 42-44).

Üretimdeki uzmanlaşma ile ürünlerin değiş-tokuşunu yapabilmek için bunu yönetecek bir otoriteye ihtiyaç duyulmuştu. Bu otorite, topluma dâhil olanların ortak bir ideolojisinin temellerine dayanması gerekmekteydi. Böylelikle bu toplumun üyeleri üretimini yaptıkları ürünlerle bu değiş-tokuşu kabul edebilirlerdi. Ürünler tanrı 
tarafından alınır ve tekrar insanlara dağıtılırdı. Tanrının evi kutsaldı ve tapınak sayılırdı. Ürünlerin toplanması ve dağıtımı bu merkez kurumunda gerçekleşmekteydi. Ubaid Dönemi'nde başlamış bir akım olarak tapınaklar, yerleşimin en görkemli yapılarıydı. Toplumdaki önemli konumlarını vurgulamak için büyük bir emek harcanmaktaydı. Uruk'ta aynı dönemde iki tapınak kompleksi bulunmaktaydı. Bunlar Eanna Kompleksi ve Anu Zigguratı'dır. Bunların ikisi de düz bir topografyada kurulu oldukları için, görkemli bir etki bırakmaktaydılar.

\section{Ur (Tel El-Mukayyer)}

Ur, Sümer ülkesinde bulunan bir antik şehirdir. Ur, kelime olarak "kent, şehir" anlamında kullanılan bir isimdir. Dünyanın bilinen en eski şehirlerinden biri olan Ur, Fırat Nehri kenarında kurulmuştur. MÖ 3500 yıllarından M.Ö 1850’ye kadar bir ticaret merkezi olarak kalmıştır. MÖ 3000'den M.Ö 2000’e kadar üç hanedanın yönetimi altında kalmıştır. Bu dönem içerisinde Sümer ülkesinin sınırları Asur’dan başlayarak Elam'a kadar uzanmıştı. İncil'de yer alan anlatılara göre İbranice dilini meydana getiren Abraham (İbrahim), Ur kentinde doğmuştur. Ur kenti Sümer ülkesinin de başkentidir (Resim 2)

1929 yılında Sir Leonad Woolley tarafindan arkeolojik kazıs1 yapılan ve Sümerlerce Urim olarak bilinen Ur, bugün “Tell el-Mukayyer” (Köroğlu, 2006: 30) (Ziftli Höyük) olarak bilinmektedir (Kramer, 2002: 18) Nuh tufanının denk geldiği yerlerden birisi olarak insanlığın ilk yerleşme yerlerindendir. Sir Woolley'in kazı yaptığı bölgede derine inildikçe çok önemli bir buluntu ortaya çıkarılmıştı. Bu, Ur şehrinin krallar mezarlığgydı. Araştırmacılar; Sümer krallarının ve soyluların gömülmüş olduğu bu mezarlıkta miğferler, kılıçlar, müzik aletleri, altından ve kıymetli taşlardan yapılmış sanat eserlerine rastlamışlardı.

Ur'da yapılan arkeolojik kazılar sonucunda iki buçuk metre kadar temiz ve hiçbir buluntu, eser içermeyen kil tabakadan geçilerek derine inilmiş ve yine bu devrin insanları tarafindan yapılmış zımpara taşından aletler ve çanak çömlek parçaları tespit edilmişti (Mallowan, 1964: 70). Ur şehrinde yapılan kazılarda ortaya çıkartılan arkeolojik bulgular; buradaki medeniyetin çok büyük bir sel felaketi sonunda kesintiye uğradığını, daha sonra zaman içinde tekrar yeni uygarlıkların meydana çıkmaya başladığını göstermektedir (Resim 5). Ur kazılarının en önemli buluntuları kral mezarlarıdır. MÖ 2500 ile MÖ 2360 arasına tarihlenen bu mezar kalıntıları çok yüksek bir kültür düzeyine işaret etmektedir. Kentin mezarlığında keşfedilen buluntular (Kuhrt, 2009, 43) (1927-29). Misır'da Tutankamon (1922-24) mezarlarındakileri gölgede 
bırakmıştır (Köroğlu, 2006: 31). Ur kenti, yaklaşık 100 y1llık bir süre (MÖ 2100-2000) Mezopotamya'nın en büyük siyasi gücünü oluşturmuştur (Günaltay, 1987: 222-241).

\section{Harran}

Güneydoğu Anadolu'nun en büyük tarihi kenti olan Harran tufandan sonra yeryüzünde kurulan ilk yerleşmedir. Çivi yazılı metinlerde "yol" anlamına gelen “Harranu” olarak geçmektedir. Ninova’yı Kargamış'a bağlayan ticaret yolu buradan geçmekteydi. Nuh peygamberin torunlarından Kaynan veya İbrahim peygamberin kardeşi Ârân tarafindan da kurulduğu düşünülen Harran, tarihin kadim devirlerinden beri, önemli bir ticaret kenti olup ayın, güneşin ve diğer gezegenlerin mukaddes olarak kabul edildiği eski Mezopotamya paganlığının en önemli merkeziydi. Ur şehrinde doğan İbrahim peygamber Filistin'e gitmeden önce vatandaşlarıyla tek tanrı inancında ihtilafa düşünce kabilesiyle birlikte Harran'a gelmiş bir müddet bu şehirde oturmuştur. Harran, İslâm öncesi dönemlerdeki en eski yerleşim yerlerinden birisidir. Kent büyük bir ziraat ve ticaret merkezi olup aynı zamanda ay, güneş ve gezegenlerin mukaddes sayıldığı eski Mezopotamya paganlığının en önemli merkezlerinden biri olmuştur. Tarih boyunca Babil, Kalde, Hitit, Asur, İran, İskender İmparatorluğu, Roma, Bizans ve İslâm devletlerinin yönetiminde kalmış olan Harran aynı zamanda dünyanın en eski üniversitesinin de kurulduğu ayrıca tıp, astronomi, fizik, matematik öğretimi yanında eski Yunanca ve Süryanice eserlerin çevirilerinin yapıldığı önemli bir bilimsel merkez olmuştur (Özfirat, 1994: 13-17). Romalılar döneminde "Carrae" adıyla anılırdı.

Harran'ın adı ilk kez MÖ 3000. yılın ikinci yarısına ait Ebla metinlerinde geçmektedir. Asurca karayolu, yol, patika, seyahat, yolculuk, kervan yolu (Yardımc1, 2007: 9), iş merkezi, sefer, akın, hizmet birimi ve matematik terimi olarak da zaman anlamlarına gelmektedir.

Kuzey Mezopotamya'yı Doğu Akdeniz kıyılarına, Que (Kilikia) ve Küçük Asya'ya bağlayan önemli kervan yolları üzerinde bulunan Harran, tarihi boyunca geçimini sahip olduğu jeopolitik konumunun da etkisi ile ticaret ile sağlamıştır. Harran'ın sahip olduğu bu jeopolitik konum önemini arttırmış ve hızlı bir nüfus artışına da zemin hazırlamıştır. Fakat bölgenin su kaynaklarının yetersizliği nedeniyle zirai faaliyetleri istenilen düzeyde gelişememiştir.

Harran tarihini aydınlatan en doğru bilgiler, yapılan arkeolojik kazılarla ortaya çıkmıştır. Harran tabirine ilk olarak, Kaneş ve Mari'de yapılan kazılarda rastlanmıştır. MÖ 2000'li yıllara ait çivi yazılı tabletlerde, "Har-ra-na” (veya "Ha-ra-na”) şeklinde adı geçmektedir. Ebla tabletlerinde ise Harran’dan “Ha-ra-na” olarak bahsedilmektedir. MÖ 
2000 yılının ortalarına ait ele geçen Hitit tabletlerinde, Harran'da bulunan Ay tanrısı (Sin) ve Güneş tanrısı (Utu) adı geçmektedir.

Harran, bir zamanlar Mezopotamya'nın en görkemli kentlerinden biriydi. Assur İmparatorluğu'nun ve Emeviler'in son başkentiydi.

Bazı yöreler ve bazı kentler Anadolu Yarımadası'nda önemli yere sahiptir, Harran da kuşkusuz bunlardan biri olmuştur. Mezopotamya ve Anadolu arasındaki oldukça önemli ticari ve coğrafi konumunun yanı sıra Tevrat'ta Hz. İbrahim'in kenti olarak anılması, Babil Kralı Babonidus'un annesinin de rahibelik yaptığı ve binlerce yıl boyunca kentin tüm Yakın Doğu'da özellikli olmasını sağlayan Ay Tanrı Sin'e ait ünlü tapınağın varlığı, önceleri bir Assur eyalet merkezi ardından da Assur İmparatorluğu'nun son başkenti olması gibi ayrıcalıklı yeri sayesinde Harran kenti, uzun geçmişi süresince önemini hep korumuştur (Özfirat, 1994).

\section{Babil}

Mezopotamya'nın en büyük ve ünlü kentlerinden biri olan Babil; Irak’ta, Dicle ve Fırat nehirleri arasında çok verimli bir sahada Samilerin bir kolu olan Amurrular tarafından kurulmuştur (Yıldırım, 2004: 54). Bugün Irak'ın El- Hilla kasabası üzerindedir. MÖ 2000 yılında Mezopotamya'nın en büyük devleti olan I. Babil Devleti (MÖ 1800-1600), burada kurulmuştur. Kuzey Babil Devleti’nin merkezi ise bugün Şırnak ilimizin İdil ilçesinin güneyinde bulunan Babil köyüdür. Babil Devleti’nin en ünlü hükümdarı, Hammurabi’dir (MÖ 1792-1750) (Günaltay, 1987: 512). Hammurabi zamanında Mezopotamya'da ilk olarak gerçek anlamda merkezileştirilmiş bir krallık kurulmuştur. Kent, yaklaşık MÖ 1450-1160 yılları arasında Kassitlerin egemenliğine girmiştir. MÖ 1110'lardan itibaren Asur Devleti burayı hâkimiyeti altına almıştır. Asur Devleti'nin ortadan kalkması üzerine MÖ 626'da bir Arami kabilesi olan Kaldeliler burada Babil halkının da içinde yer aldığı Yeni Babil Devleti'ni kurmuşlardır (MÖ 626539). Şehir, MÖ 539-331 arasında Pers egemenliğine girmiştir. Büyük İskender'in MÖ 331'de Persleri yenilgiye uğratmas1, Babil'in İskender İmparatorluğu'na dâhil edilmesine neden olmuştur. Çivi yazılı metinlerden anlaşıldığına göre Babil kentinin Uraş, Zabaka, Marduk, Enlil, İştar, Samaş, Adad ve Sin adında sekiz kapısı vardır. Dünyanın yedi harikası olarak adlandırılan "Babil'in Asma Bahçeleri”, Koldowey’in (Koldowey 1914) kazıları ile ortaya çıkarılmıştır (Resim 2). İskender'in Babil'de bulduğu söylenen astronomi cetvelleri ile Babil adetlerine göre günün 24'te birine eşit zaman parçasını ifade eden Babil saatleri, yeryüzünde dillerin ilk olarak ortaya çıktığı rivayet edilen Babil kulesi, Babil kralı Nabukadnezar'ın Yahudilerin Misırlılar ile 
birlikte yürüttüğü entrikalar üzerine MÖ 586'da Kudüs’ü ele geçirerek Yahudileri sürgüne gönderdikleri yer ve Hammurabi Kanun metinlerinin yazıldıkları yer olarak Babil kenti dünya tarihinde önemli yerini almıştır (Erdem, 1991: 392-395; Herzfeld, 1979: 177-179).

Babil toplumunda kral, çoban ve çiftçidir. Bu dönemde saray yalnızca tapınaklar ve onların ekonomik olanaklarından yararlanmamakla yetinmemiş tapınak toprakları devletleştirilmiştir. Tapınaklardaki rahipler ise kralın memur sürüsüne katılmışlardı. Üç sosyal sinif mevcuttu, bunlar:

$\begin{array}{lll}\text { - } & \text { Awilum } & \text { (Özgür Adam) } \\ \text { - } & \text { Meşkenum } & \text { (Bağımlı) (Tosun, 1973: 272) } \\ \text { - } & \text { Wardum } & \text { (Köle) }\end{array}$

$\mathrm{Bu}$ sosyal sınıflardan Bağımlıların statüsünü anlamak oldukça zordur. Bağımlılar; tüm gün sarayda çalışır ve hizmet ederlerdi, çok nadir dışarıdan hizmetçi alınırdı. Yasalar bir kişinin statüsüne göre değişebilmekteydi. Cezaların ağırlığı da buna göre şekillenirdi. Babil krallarından Hammurabi, tanrı krallardan değildir. Tanrılar tarafından görevlendirilmişti. İktidarı meşru idi ve kim buna karşı gelirse günah işlemiş olurdu. Hammurabi, kendisini Güneş ve Adalet Tanrısı Şamaş'ın, gözdesi olarak tanıtmaktadır. Hammurabi'nin tanrı kenti olan Sippar'ı bir ara başkenti yapması, ona bağlılığını göstermektedir. Babil'in baş tanrısı ise Marduk'tu. Fakat bu tanrı Hammurabi ve ardılları tarafından çok öne çıkarılmamıştır. Kral tapınaklara egemendi onları emrine bağlamıştı ve onlardan sorumluydu. Kurban sunumu ve tapınakların onarılmasını, geçinmesini sağlama görevleri krala aitti. III. Ur'dan itibaren de tapınaklar sadece tanrının evi değil tanrının sarayı durumundaydılar ve artık yalnızca bir tür hayırsever kurum değil en üst ahlaki merci konumuna ulaşmışlardı (Quates, 2004: 7174).

\section{Kudüs}

Tevhid akidesinin merkezi olan Kudüs, "kutsal ve temiz” anlamına gelmektedir. Akdeniz ile Kızıldeniz arasında yer alan Kudüs, Tel Aviv'in 40 km güneydoğusunda ve denizden 750 metre yüksekte bir sırt üzerinde kurulmuştur. Yeruşalayim, Jerusalem, Uruşelim, Yerusalim, İlya, Eliya, Moriya, Makdis, Beyt-ül Makdis, olarak da bilinmektedir (Harman, 2002: 323-332 ; Buhl, 1979: 952-964).

Kudüs; MÖ 4000'li y1llara kadar uzanan tarihi ile Museviler, Hristiyanlar ve Müslümanlar tarafından kutsal kabul edilen bir şehir olmuştur. Kudüs; Hristiyanlar, 
Yahudiler ve aynı zamanda da Müslümanlar tarafından mukaddes bir şehir olarak hürmet görür. Mescid-i Aksa, Ağlama Duvarı ve Kıyamet Kilisesi şehrin ev sahipliği ettiği her üç dinin en belirgin göstergeleridir.

Son Tunç Çă̆'da MÖ 2000-1550 Kenanlıların soyundan gelen Yabusilerin kontrolünde olan şehirde (Tanlak, 1988: 18) Tanrı Salem adına bir tapınak yapılmış ve şehir ulu "İlah Salem” adıyla anılmıştır. Kudüs bir Kraliyet şehriydi. En bilinen kralları Kadum Salem, Malkisadek ve Adoni Sadek olarak tanınıyordu. Tevrat'ta Salem adlı bir şehrin kralından söz edilmektedir. Eski İbrani paralarında Yerushalayim olarak geçen isim; Aramice "Yerushlem”, Süryanice "Urishlem” ve Asurca "Urusalim” şekillerinde geçmektedir. Salem, İbranice "Şalim” köküne dayanmaktadır ki, bugün o kelime “Yeruşalim” olarak okunmaktadır. İbranice “Şalim”, Arapça “Salem” ile aynı kökten kaynaklanmakta olup her ikisi de barış anlamındadır (Sarı, 1982: 775). Tarihte Arami ya da Babil kaynaklı kelimeler olarak "Varya Salem” ve "Yaro Salem” olarak da geçmektedir. Yine Kenanlıların bir kolu olan Jebusitler'den ötürü MÖ 1400 dolaylannda Kudüs’e “Jebus” dendiğini de söyleyebiliriz.

MÖ 996 yılında Kudüs, Davut peygamber tarafından kurulan İsrail krallığının başkenti olmuştur. Davud'un şehri almasına kadar “Sion” adının kullanıldığı ve ele geçirilmesinden sonra da şehre "Davud Şehri” denildiği bilinmektedir. Kral Davut, Hz. Musa'nın ahit sandığını buraya getirmiş ve onun ölümüyle birlikte oğlu Kral Süleyman MÖ 960 yılında Beytü-1 Makdis’i inşa ettirerek ahit sandığını buraya yerleştirmiştir.

Kudüs, MÖ 500 yılında Babilliler tarafından ele geçirilmiş ve buradaki Yahudiler, Nabukadnezar tarafından Babil'e sürgüne gönderilmiştir (Günaltay, 1987: 315-343). Öldürülmeyen İsraillilerin Babil'e götürülmeleri ve orada köle edilmeleri MÖ 586 yılında başlamaktadır. Pers İmparatoru onların ancak 50 yıl sonra dönmelerine izin vermişti ancak az bir kısmı geri dönebilmişti. Bu işgallerde yerli halk içinde bir bölümü toprağından hiç ayrılmamıştı. Kudüs'te kalan Kenanlılar ve onların kolu Jebusitler, kuzeyden inen Hititler, Kudüs'ün ve Filistin'in yerli halkını oluşturmağa devam etti.

Büyük İskender Hellespontos’dan geçinceye kadar bu topraklar iki yüz y1l kadar barış içinde kaldı. İskender Kudüs'e adımını hiç atmadıysa da, ordusunun Mısır'a kadar uzanmasıyla Kudüs 960 yıl kadar önce Hellen, sonra da Roma tesirlerine açık kaldı. Roma komutanı Pompeius, Roma adına Suriye'ye müdahale ettiğinde Filistin de bu kanadın altına girmiş ancak yönetimde bir derece özgürlük kazanmıştı. Hükümdar Herodes'in oğullarının yönetimi entrikalarla doluydu. İsa'nın Beytlihem'de (Bethlehem) doğumu da bu zamana denk gelmektedir. Farklı bir öğretiyi yaymağa 
çalışan İsa'nın öğretisi, Kudüs'te ve Filistin'de baskı altında tutulmuş ancak bu defa başka topraklarda yayılmağa yüz tutmuştu. Ne var ki bu baskıya yenilerinin de ilave edilmesiyle birbirini izleyen isyanlar İmparator Konstantin'in MS 325 y1linda Hristiyanlığı kabulüyle durulmuştu. Bu dinin ilk önemli yapıları işte bundan sonra görülmeye başlamaktadır. İsa'nın çarmıha gerilmeye çalışıldığı yerde kurulan kilise bu döneme aittir. Ancak Perslerin sallanan Roma İmparatorluğuna bu topraklarda darbeler vurmaya başladığı bu sıralarda, güneyde Müslüman Araplar kuzeye doğru yayılıyorlardı (Türkkaya, 1981: 31-32). MÖ 100 yılına gelindiğinde Kudüs, Romalılar tarafından ele geçirilmiştir. Kudüs'te Tapınak Dağı ile Ağlama Duvarı olarak bilinen Batı duvarı Yahudiler için İsa'nın göğe yükseldiğine inanılan yer olan Kutsal Sepulchre kilisesi Hristiyanlar için Mescid-Aksa (en uzak mescit) ile Kubbet-üs Sahra'da Müslümanlar için kutsal olarak bilinmektedir. Kudüs Kur'an'ın da ifade ettiği gibi, Hz. Muhammed'in Mekke'den Kudüs'e geceleyin yaptığı mucizevi yolculuğa (İsra) tanıklık etmiş ve İslam kaynaklarına göre Hz. Peygamber Kudüs’ten göklere çıkmıştır. Kudüs, Hristiyanlık dini için kutsal bir sığınak ve bir başlangıç yeridir. Hz. İsa da Hristiyanlık da bu kutsal kentte doğmuştur. Hristiyanlar için büyük önem ittihaz eden Kutsal Gömüt, Veladet Kilisesi ve daha birçok Hristiyan tapınağı oradadır. İsa'nın doğumu, yaşamı ve ölümüyle ilgili tüm yerler Kudüs'te ve hemen onun çevresindedir. Kudüs’te Hristiyanlık deyince içine Roma Katolikliği, Yunan ve Rus Ortodoksluğu, Ermeni, Kıpti, Maruni ve birçok Protestan Kilisesi girmektedir (Edwin, 1973).

\section{Sümer ve Babil Kanun Metinleri}

Mezopotamya'da hukuk ve kanun yazma geleneği Sümerler ile başlamıştır. Sümerlerin hukuki belgelerin düzenlenmesinde, kullanılan üslup, ifade ve formüller konusunda kalıplaşmış bir sistemleri vardı. Bu gelenek ve kanun yazma tekniği zamanla Mezopotamya'da yaşamış tüm toplumları etkilemiştir.

Bütün toplumlarda olduğu gibi Sümerler de yazılı hukuka, örf ve adet hukuku ile geçmişlerdir. Elimizde MÖ 3000 yılından kaldığı tahmin edilen Sümerlere ait ev, tarla, eşya gibi malların satışına ait belirli formlarda yazılmış ve tanıkların da belirtildiği belgelere rastlanmıştır (Kramer, 2002: 42-49). Bu belgeler bize, Mezopotamya'da yaptırımları da içeren bir hukuk düzeninin ve buna bağlı olarak bir hukuk geleneğinin oluştuğunu göstermektedir (Bilgiç, 1963: 103-107). Bu dönemdeki metinlerin hukuki niteliğinin ne olduğuna ilişkin pek çok görüş ortaya atılmıştır. Kimine göre bu metinler sözlü gelenek ve uygulamaların yazılı hâle getirilmesi ihtiyacı ve mevcut hukuklarını değişen ekonomik, politik ve sosyal şartlara uygun olarak güncelleme ihtiyacıdır. 
Bundan farklı diğer bir görüş ise, bu metinlerin tamamen bir örf ve adet derlemesi olduğu düşüncesidir. Bir kısım araştırmacı ise bunların sadece hukuk formüllerini ve ideal toplumu tarif eden hayalî metinler olduğunu, kanunların uygulandığına ilişkin belgelerin var olmadığını ileri sürmektedir. Kanun metinlerinin kralın tanrılara ve gelecekteki krallara, hatta insanlara sunduğu bir vasiyeti ve kendi iktidar döneminde yaptıklarına ilişkin bir savunması olduğu düşüncesini benimsemektedirler (Wersteeg, 2000: 13-15).

Yeryüzünün bilinen en eski adalet belgesi Sümer kökenli olup, ezilen halk1 rahiplerin ve yöneticilerin baskısından kurtarmak ve ülke idaresini düzenlemek amacıyla Lagaş Kralı Urukagina (MÖ 2351-2342) tarafından hazırlanmıştır (Tosun, 1989: 11). Lagaş kralı Gudea (MÖ 2100) ise baş tanrı Ningirsu tapınağına diktirdiği heykeli üzerine kazdırdığı ıslahat yazıtında zengine fakiri, güçlüye zayıfı ezdirmediğini reformlarında bahsetmiştir (Tosun-Yalvaç, 1989: 11-12) (Resim 6). İlk gerçek yasa metni III. Ur sülalesinin kurucusu Ur-Nammu (MÖ 2111-2094) tarafindan yazdırılmıştır. Hazırlanan kanun metinlerinin ilk kısmı "büyücülüğe, asker kaçaklığına ve yaralamaya" aittir. (Dinçol, 2003: 5). Ana İttişu adı verilen kanunlar ise "vadesi gelinceye kadar" demek olup aile hukuku, köle kiralanması, fiyat tespitleri ile ilgili metinler içermektedir (Bahar, 2011: 82). İsin kralı Lipit-İştar (MÖ 1934-1924) yasaları Eski Babil devrine ait yasalar olup bunlar Hammurabi yasalarının prototipidir (TosunYalvaç, 1989: 13-14; Dinçol, 2003: 8-9). Eşnunna krallığı yasaları ise kral Daduşa zamanında yazılmış ilk Akkadça yasa kodeksidir. Hammurabi öncesi kanunlar hem Sümerce hem de Akkadca ile yazılmıştır (Tosun-Yalvaç, 1989: 10).

Başlangıçtan itibaren belirli bir kalıp şeklinde yazılmış olan bu kanunlarda önce bir prolog, sonra hükümleri içeren bir kanun metni ve en sonunda da epiloğu bulunmaktadır. Bu sistem tüm Mezopotamya toplumlarınca uygulanmış bir yöntemdir. Kanunların özelliğine ilişkin bir diğer hususta, epilog ve prologlarda, kralın tanrılar tarafından çağrıldığına, adalet ve özgürlüğü sağladığına, insanları hoşnut ettiğine ilişkin ifadeler bulunmasıdır. Bu ifadelerin temeli Sümerlere dayanmakla beraber, tüm Sümer ve Sami kökenli krallar tarafindan belli bir din ve devlet anlayışı ve etkisiyle kanun metinlerinde yer almaktadır. $\mathrm{Bu}$ ifadelerden kralların, halka onların refah ve mutluluğunu sağlama gayreti içinde olduklarını duyurmayı ve bunun sonraki nesiller tarafından da bilinmesini istedikleri anlaşılmaktadır. Ayrıca bütün kanunlarda, tanrıların sözlerinin yerine getirildiğine ilişkin ifadeler bulunmaktadır (Bilgiç, 1963: 115-119). 


\subsection{Urukagina Kanunları}

Urukagina Kanunları, bilinen ilk Sümerce hukuk metnidir. MÖ 2400 yıllarında yazıldığı tahmin edilen metinde "güçlünün güçsüzü ezmeyeceği” bir anlayış hâkimdir (Tosun-Yalvaç, 1989: 11). Metin kanun yapma geleneğine uygun olarak üç kısımdan oluşan metinde bir prolog, kanun metni yerine talimatlar içeren kısım ve bir epilogu bulunmaktadır. Prolog kısmında Lagaş beyi ile rahiplerin işbirliği yaparak halkı nasıl sömürdükleri anlatılmaktadır. Daha sonra yolsuzluk yapan memur ve rahiplerin görevden uzaklaştırıldığı belirtilir ve yeni vergi ve fiyat ayarlamaları ilan edilir. Epilog kısmında ise, Urukagina'nın yaptığı yeniliklerden, özgürlükleri yeniden tesis edişinden ve tanrının sözünü yerine getirdiğinden bahsedilmektedir (Dinçol, 2003: 5). Kanunun metninin amacı, önceki iktidar döneminden kalma yolsuzluk ve huzursuzlukları kaldırmaktır. Getirilen reformlar arasında en dikkat çekici olan, boşanmalarda erkeğin ödediği ağır nafakanın kaldırılmış olmasıdır (Bilgiç, 1963: 108). Nafakayı ödeyemeyen erkek, karısının tekrar başka bir erkekle evlenmesini engellemiyordu, böylece çok kocalılık (poliandri) durumu ortaya çıkmaktaydı. Bu düzenlemeyle çok kocalılık durumunun önüne geçilmektedir ve eğer bir kadın birden çok eş alırsa suya atılma cezası almaktaydı (Memiş, 2007: 150) (Resim 7).

\section{2. Ur-Nammu Kanunu}

Eski Mezopotamya'da bulunmuş ve MÖ 2100 yıllarında III. Ur sülalesinin ilk kralı olan Ur-Nammu tarafindan yazdırılmış ilk gerçek yasa metnidir (Tosun, 1973: 566). Üç tabletten oluşan kanunun uzun bir proloğu ve kırka yakın maddesi bulunmaktadır. Epilog kısmı yoktur (Dinçol, 2003: 5). Kırık ve eksik olarak ele geçirilen tabletlerde mevcut hükümlerin de çoğu tam anlaşılamamaktadır (Bahar, 2011: 77). Prolog kısmında tanrılar tarafından nasıl kral seçildiğinden kralın egemenliğini memleketin üzerinde nasıl tesis ettiğinden, eski iktidar döneminin ahlaksızlıkları ve yolsuzluklarından bahsedilmiş ve Ur-Nammu'nun reformları ile bunları düzelttiğini, tartı ve ölçülerde yeni ayarlamalar yaptığını belirtmektedir (Bilgiç, 1963: 108-109). Kanunda yer alan hükümler genellikle usul hukukuna ilişkin olarak yalan suçlamalar, mülkiyete ilişsin olarak kaçak köleler, ceza hukukuna ilişkin olarak yaralamalar ve aile hukukuna ilişkin olarak da evlilik konularına ilişkindir (Tosun-Yalvaç, 1989: 30). Kanunun en dikkat çekici özelliği ise oldukça insancıl bir yapıda olmasıdır. Gerçekten de sadece üç hükmünde ölüm cezası ve bir hükmünde hapis cezası görülmektedir. Diğer hükümlerde genel olarak para cezası uygulanmaktadır. Kanunda pek çok değerin yükseltildiği ve pek çok menfaatin korunduğu gözükse de genel olarak daha yüksek 
sınıfların menfaatinin korunmasının öncelikli olduğu gözden kaçmamaktadır (Versteeg, 2000: 21-24).

\subsection{Ana-İttişu Kanunu}

Hem Sümerce hem de Asurca olarak Asurlu katiplere Sümerceyi öğretmek için iki dilde yazılmıştır ve yedi tabletten oluşmaktadır. İlk kelimesi, “Ana-İttişu” olduğu için bu adla anılmaktadır. Kanun metni "vadesi gelinceye kadar" ifadesi ile başlamaktadır (Dinçol, 2003: 6). Tam olarak kimin tarafından ve ne zaman yazıldığı belli olmayan Kanun'un bazı maddelerinin Ur-nammu Kanunu'na benzemesi III. Ur sülalesi zamanında yazılmış olabileceği sonucunu çıkarmaktadır (Memiş, 2007: 152). Kanun metninde aile hukukuna, köle kiralanmasına ve fiyat tespitlerine ilişkin hükümler bulunmaktadır (Tosun-Yalvaç, 1989: 44).

\subsection{Lipit-İștar Kanunu}

İsin şehrinde hüküm süren İsin sülalesinin beşinci kralı olan Lipit-Işstar tarafindan yapılan kanun metni tahmini MÖ 1920'li yıllarda yazılmıştır. Kanun Sümerce yazılmıştır fakat Lipit İştar ve sülalesi Sami kökenlidir. Bunun sebebi, son Sümer devleti olan III. Ur Sülalesi'nin egemenliğinin daha yeni çökmüş olması ve İsin şehri halkının çoğunun Sümerli olmasıdır. Dinî olarak da Sümer kültürünün etkisi hâlâ devam etmektedir (Memiş, 2007: 152-154).

Kanunun bir proloğu, bir epilogu ve günümüze kalmış okunabilen kırka yakın maddesi bulunmaktadır. Prolog kısmında kralın memlekete adalet getirmek, Sümer ve Akkadlıların bedenlerini hoş etmek için tanrılar tarafından göreve çağrıldığından bahsedilmektedir. Epilogda ise, aynı konular üzerinde durulmuştur. Ayrıca kanun hükümlerine uyulması gerekliliğinden bahsedilmekte ve gelecekte uymayanların ya da kanun metninden Lipit-Işstar'ın adını silenlerin lanetleneceği bildirilmektedir (Bilgiç, 1963: 110-111).

Şekil açısından incelendiğinde maddeler genellikle "eğer”, Sümercesi “tukumbi”, ifadesi ile başlamaktadır (Roth, 1997: 24). Kanun'un okunabilen maddeleri, gemi inşaatına ve kiralanmasına, özellikle vergiye ilişkin olarak gayrimenkullere, özellikle evlenmeye ilişkin olarak aile hukukuna, kölelik, tımar, veraset ve hayvan kiralaması konularına ilişkindir (Bilgiç, 1963: 111). Ayrıca “miqtum” adı verilen özel bir sınıfa ilişkin hükümleri de içermektedir (Dinçol, 2003: 7).

Ağırlıklı olarak mal sahibinin menfaat ve haklarının düzenlendiği kanunda söz konusu mallar; öküz, gemi, meyve bahçesi ve diğer tarım alanları ve kölelerdir. Aile 
hukukuna ilişkin düzenlemeler, kanunda en geniş yeri tutmaktadır. Evlilik dışı doğan çocukların miras ve sosyal durumlarına ilişkin düzenlemeler yapılmış olan kanunda ayrıca yargılama sürecinin zayıf, yanlış ya da yalan ithamlar karşısında güvenliğini ve sağlamlığını sağlamak için yalancı tanıklığa ilişkin bir maddesi de mevcuttur. Kanun metninde ölüm cezası sadece hamile kadına yönelik yaralama ya da öldürme eylemlerine karşı uygulanmasını öngören maddeler mevcuttur ( Versteeg, 2000: 25-27).

\subsection{Eşnunna Kanunu}

Sadece Akkadça olarak yazılmış elimize geçen ilk kanun metnidir (Tosun, 1973: 569). Hammurabi Kanunu'ndan kısa bir süre önce yazıldığı tahmin edilmektedir. Lipitİştar, Urnammu ya da Hammurabi Kanunu'ndan farklı olarak bu kanun, yapan kişinin adıyla değil de yapıldığı şehrin adıyla anılmaktadır (Versteeg, 2000: 27). Bunun sebebi kanunun giriş kısmının kırık olmasıdır. Tam olarak hangi zamanda ve hangi kral tarafindan yapıldığı bilinmemektedir. Kral Daduşa olarak tahmin edilse de aksi görüşte olanlar da vardır (Dinçol, 2003: 7).

Bir epilog ya da bir proloğu bulunan kanunun sadece kısa bir girişi vardır. Burada, kralın tanrı Enlil tarafından seçildiğine ilişkin ifadeler bulunmaktadır. Kanun, altmışa yakın hüküm içermektedir (Bilgiç, 1963: 111-112). Eşnunna Kanunu’nda hükümler çeşitli şekillerde yazılmıştır. Genel olarak "eğer", Akkadça ifadesi "şumma” kelimesi ile hükümler başlamaktadır. Ayrıca "bir adam ki...", “awilum şa” ifadesi ile başlayan hükümler de yer almaktadır. Fiyat ve kiralama durumlarına ilişkin hükümler ise "bir tüccar...meyecek..." şeklinde uygulanmıştır (Roth, 1997: 58).

Kanun'da en geniş yeri fiyat ve kira bedellerinin ayarlanmasına ilişkin finansal konulara yönelik hükümler tutmaktadır. Ayrıca düğün hediyelerine, çocukların bakımı ve yetiştirilmesine ve boşanmaya ilişkin hükümlerde aile hukukuna yöneliktir. Borçlar hukukuna ilişkin hükümler, borç iddiası ve haksız haciz konularına yöneliktir. Bunlar dışında emanete, köleliğe, kamu görevlilerinin görevlerini kötüye kullanmalarına ilişkin maddeler de bulunmaktadır. Kanunda en dikkat çekici nokta ise kamu güvenliği ve refahını ilgilendiren, ev bekçisinin sorumluluğu, zayıf duvarın ev sahibine verdiği zarardan ötürü sorumluluk ve hayvan zararlarına (köpek ve öküzlerin) ilişkin hükümlerdir.

Kanun hükümleri incelendiğinde birçoğunun daha çok yüksek sınıfın menfaatlerini koruduğu gözlemlenmektedir. Pek çok fiyat ve kira bedellerinin ayarlanmasına ilişkin hüküm bulunmaktadır. Kanunda kamu güvenliği ve refahına 
yönelik ve sosyal değerleri destekleyici nitelikte aile hukukuna ilişkin maddeler mevcuttur (Versteeg, 2000: 20-31).

Eşnunna Kanunu, daha çok zirai nitelikte hükümler içermektedir. Gayrimenkullerde müşterek aile mülkiyeti anlayışı hala kuvvetlidir ve bu nedenle doğal ekonomiden para ekonomisine geçiş sürecini temsil etmektedir. Fakat Eşnunna Kanunu'nda pek çok hüküm yaptırımsız olarak kalmıştır (Bilgiç, 1963: 112).

\subsection{Hammurabi Kanunları}

Bu kanunlar, MÖ 1760 yıllarında Mezopotamya'da ortaya çıkan tarihin bilinen en eski ve korunmuş yazılı kanunları arasındadır (Dinçol, 1963: 8). Bu dönemden önceki yasa koleksiyonları arasında Ur kralı Ur-Namnu'nun oluşturmuş olduğu kanun kitabı (MÖ 2050), Eşnunna (MÖ 1930) ve İsin'li Lipit-İştar'ın kanun kitapları (MÖ 1870) yer almaktadir.

İlk Babil kanunları, Hammurabi (MÖ 1793-1750) tarafından edebi üslupla yazılmış bir “prologue/önsöz” ve bir “epilogue/sonsöz” olmak üzere var olan kanunların düzenlenmiş yeni şekilleri ile yeni ilave maddelerin ortaya konması ile 282 maddeden ibaret olarak hazırlanmıştır. Genel olarak kanunda yer alan hükümler "eğer”, "şumma” ifadesi ile başlamaktadır (Memiş, 2007: 158; Roth, 1997: 72). Hammurabi Kanunu'nu, diğer kanunlardan ayıran en önemli özellik ise epilog ve prologu da dâhil olmak üzere diğer kanunlardan çok daha uzun, detaylı ve sistematik oluşudur. Hammurabi Kanunu hem daha önce yapılmış olan kanunların ve örf adet hukukunun bir derlemesiyle hem de zamanın yeni çıkan ihtiyaçlarını dikkate alınarak oluşturulmuştur (Bilgiç, 1963: 113). Fasih ve klasik bir Babilce ile kaleme alınmıştır. Hammurabi'nin bu kanunları imparatorluğa geçiş sürecinde bölgelere göre değişmeyen bir hukuk ve yönetim anlayış1 kurmak için yaptığı sanılmaktadır (Resim 1) (Memiş, 2007: 158).

\section{Prologue}

...Vaktinde, üstün Anum..gögün ve yerin efendisi Enlil, memleketin kaderini tayin eden Ea'nın büyük oğlu olan Marduk için bütün insanlık üzerine Enlil'’ğini (krallığını) onun tayin etti... Babil Şehrini üstün adıyla andı; Onu cihanda üstün yaptı. (orada) temelleri gök ve yeri gibi sağlam olan ebedi bir krallık sağladı. O günde methedilmiş kral, tanrı korkusu olan ben Hammurabi'yi, memlekette adaleti tecelli ettirmem için, şikayet ve kötüyü yok etmem için, kuvvetlinin zayıfı yok etmemesi için, güneş gibi kara başların (insanların) üzerinde yükselmem için, memleketi aydınlatmam için...... Anum ve Enlil adımı andılar. Enlil'in çağırdığı çoban Hammurabi'yim ben..... . Krallığın ebedi tohumu, kuvvetli kral, Babil'in güneşi, Sümer ve Akkad memleketleri üzerine nur yağdıran dört cihana boyun eğdirten kral, İştar'ın sevgilisiyim ben. Marduk, insanları doğru idare etmem ve memleketin idaresini 
ele almakla beni görevlendirdiği zaman, memleketin diline doğruluk ve adalet koydum... (Tosun-Yalvaç, 1989: 181).

\section{Epilogue}

...Tanrı Enlil'in bana hediye ettiği, çobanlığın tanrısı Marduk'un bana verdiği kara başları (insanları) ihmal etmedim...Aydınlığı onların üzerine çıkarttım. Tanrı İnanna ve Zababa'nın bana emanet ettikleri kuvvetli silah ile Enki'nin bana verdiği görüş kuvveti ile, Marduk'un bana verdiği güç ile yukarda ve aşağıdaki düşmanı söküp attım...Koynumda Sümer ve Akkad memleketlerinin insanlarını taşıdım...Göğün ve yerin büyük hakimi olan tanrı Şamaş’ın emriyle adaletim memlekette tecelli etsin..Hakkı yenilmiş ve şikayeti olan adam, adaletin kralı olan benim heykelimin önüne gelsin. Yazılı stelimi okusun. Gelecek günlerde sonsuzluğa kadar var olacak olan kral, ..memleket hükümlerini değiştirmesin. Kitabelerimi kenara atmasın. Eğer o Adam, stelimdeki söze dikkat etmezse, (80 satır lanetleme) , o adam ister kral, ister bey, ister Ensi veya adı ne olursa olsun halkının dağılmış olması, krallığının devrilmesi, hayatının su gibi akması, Tanrı Şamaş yukarı hayattan onu ayırsın, aşağıda, yerde ruhlarını suya susatsın., saltanatının günlerini, aylarını ve yıllarını ızdırap ve göz yaşı içinde bitirsin. Tanrı Adad, memleketini kıtlık ve açlıkla mahvetsin, tanrı Zababa savaş yerinde onun silahını kırsın, Tanrıça İnanna onun hükümranlığını lanetlesin onun iyiliğini kötülüğe çevirsin, onun kahramanlarını yere vursun onların kanları yeri sulasın. Ordusunun ceset yığınlarını kırlara döksün. Memleketin yüksek sahibesi Nintu, beni dünyaya getiren Ana, onu evlat sahibi yapmasın. İnsanlar arasında insanlık tohumuna sahip kılmasın. Tanrı Anum'un kızı Ninkarrak, ağır bir hastalığı, kötü bir hastalık cinini, iyi olmayacak bir yarayı, hekimin bilemediği sargılarla saramadığı, onun vücuduna yerleştirsin, nefesi sönene kadar kaybolan kudreti için ağlasın... (TosunYalvaç, 1989: 211).

Prolog kısmında baş tanrı Marduk hakkında övücü sözler bulunmakta ve Marduk ile adalet tanrısı Şamaş tarafından nasıl kral seçildiğinden bahsedilmektedir. Ayrıca Hammurabi, adalet ve doğruluğu tesis ettiğinden Babil ve komşu şehirlere huzur ve refahı getirdiğinden söz etmektedir. Söz konusu şehirlerin adlarını ve Hammurabi'nin bu şehirler üzerinde ne zaman hakimiyet kurduğunu incelediğimizde, bu kanunun iktidarının yirmi iki ila yirmi üçüncü yıllarında yapıldığı anlaşılmaktadır. Epilog kısmında ise aynı hususlar tekrarlanmakta ve ilave olarak, halkın ağzından şikayetleri sildiğinden, zenginin fakiri, güçlünün zayıfı ezmesinin engellendiğinden bahsedilmektedir. Son olarak, gelecekteki kralların ve insanların bu kanununa uyması öğ̈̈tlenmekte ve kanunun yazıldığı anıtı tahrip edenin veya üzerinden Hammurabi’nin adını silenin lanetleneceğinden bahsedilmektedir (Tosun, 1963: 130-131).

Hammurabi kanunları Eski Babilce yazılmış olup, 2.25 m. yüksekliğinde diorit bir dikme taşa 49 sütun hâlinde kazınmıştır. 1901-1902'de bir Fransız arkeolog başkanlığında yürütülen Susa kazılarında bulunmuştur. (Louvre) Stelin üst kısmı, 
Adalet ve Güneş Tanrısı Şamaş'1 bir taht üzerinde oturmuş ve önünde dua eder şekilde duran Hammurabi'yi tasvir etmektedir. Yazıt eski çiviyazısı belgeler gibi dikey olarak kesilmiştir. Gerçek anlamda bir yasa derlemesi değildir. Kapsamı geniş değildir ve hiçbir yerinde hükümlerin yerine getirecek özel hâkim veya benzeri memurların yemini yoktur (Mieroop, 2012: 95). Hammurabi tarafindan açıkça ölüm cezası öngörülen birçok suç için daha sonraki kral Ammi-Saduka'nın bir fermanla karşı yasalar çıkarmasından anlaşılmaktadır. Yasa maddeleri, mülkiyet tasarrufu ve mesuliyet ile ticaret hukukunun bazı alanları ağırlıkta olmak üzere çok değişik konuları kapsamaktadır. Hammurabi kanunlarından sonra eski Mezopotamya'nın en önemli hukuk belgesi orta Asur devrine ait olan (MÖ1450-1250) Asur kanunlarıdır (TosunYalvaç, 1989: 15). 14 tablet hâlinde il devrine ait (MÖ 625-539) kırık tablet evlilik ve veraset ile ilgilidir (Dinçol, 2003: 9). Eski Babil kanunları, Sümer kanunları örnek alınarak hazırlanmıştır (Tosun-Yalvaç, 1989: 16).

\section{Mısır ve Sümer'deki Resim ve Çivi Yazıları}

Yazı, en büyük medeniyet unsurudur. Hiyeroglif (kutsal yazıt) yazı, 700’den fazla işaretten oluşmaktayd. Her bir işaret özel bir sesi ve nesneyi temsil etmekteydi. Cisimlerin yönüne göre soldan sağa veya yukarıdan aşağıya olarak yazılabilirdi. Önceleri levhalar üzerine kazılan bu yazı, sonradan kazılmayıp yazılınca resimlik vasfı kaybolarak Hieratik yazı haline dönüştü. Hieratik yazının da kısaltılıp kullanışlı bir hâle gelmesiyle Demotik yazı meydana geldi (İnan, 1992: 254). Hiyeroglif yazının Hieratik şekli, Yunan ve Romalı din adamlarınca kullanılırken 25. ve 26. hanedan zamanından itibaren Demotik şekli de günlük hayatta kullanıldı. Philae adasındaki kutsal İsis tapınağında en son hiyeroglif yazılar yazıldı. İlk olarak Fransız dilci Jean- Francois Champollion tarafindan 1822 yılında okundu (İnan, 1992: 21). İnsanlık tarihinin en önemli buluşu olan yazı ilk olarak Sümer rahipleri tarafından tapınak ve depolarda bulunan malları kaydetmek için MÖ 3200 yıllarından itibaren geliştirilmiştir (Yıldırım, 2004: 66-67). Tüm yazı türlerinin Sümer yazısından kaynaklanmış olması kuvvetle muhtemeldir. Yumuşak kil üzerine sivriltilmiş uçlu kamış parçaları ile şekiller çizilerek gerçekleştirilmiştir. Kil tabletin kızgın fırınlarda pişirilmesi ile yazı kalıcı hale dönüştürülmüştür (Köroğlu, 2006: 54).

Yazı birdenbire ortaya çıkmamış zamanla geliştirilmiştir (Hırçın, 2000: 22). Önce mağara duvarlarına yaşanılan olaylar resmedilmiş zamanla bunlar geliştirilerek ideografik yazı ortaya çıkmıştır. Çivi yazısı İran'dan Anadolu'ya ve tüm dünyaya 
yayılmış ancak öğrenilmesi çok kolay olan Fenike alfabesi çıkınca kullanılmaz hale gelmiş ve zamanla unutulmuştur (Kınal, 1963: 1-10).

Yazı, devlet yapısında ve gelişen ekonomik ilişkiler çerçevesinde ortaya çıkan karışıklıkları önlemek ve çalışmaları düzene koyma çalışmalarının bir sonucu olarak ortaya çıkmıştır. Güney Mezopotamya'nın nüfus oranları gelişen kentlerinde, merkezi idarenin devam ettirdiği inşa projeleri arttıkça, tapınak ambarlarında toplanan ve buradan dağıtılan ürünlerin miktarı çoğaldıkça bunların hesaplarının tutulmasına yardımcı olan basit işaretler, sayılar ve listeler ihtiyacı karşılayamayacak bir vaziyet almıştır. Yazı, çok yönlü ve karmaşık verileri düzenlemek maksadıyla bu engelleri aşmak için geliştirilmiştir. Yaygınlaşan yazı zaman içerisinde küçülerek resim özelliğini kaybetmiştir. Tabletlere çizilen yatay hatlar üzerine resim karakterinden devşirilen çivi biçimli işaretler yapılmaya başlanmıştır. Çivi işaretleri, değişik pozisyonlarda dikey veya yatay biçiminde ıslak kile uygulanıyordu. Sözcükler çivi yazısında tek bir işaretle değil, her biri sadece bir heceyi gösteren çivi işaretleri ile yazılıyordu. Ayrıca eski sistemin devamı olan, işaretler de kullanılıyordu (Köroğlu, 2006: 54). Zamanla dilin yapısına göre karmaşık, ancak belli kuralları olan bir yazı sistemi oluşmuştur. Bu gelişim süreci, 3000. yılın ortalarına kadar tamamlandı ve gerçek anlamda bir çivi yazısı oluşmuştur. Sonraları çivi yazısını kendine uyarlayan her toplum, dillerinin özelliklerine uygun değişiklikler yaparak bu sistemi geliştirdi (Resim 3).

Yazının yaygınlaşmaya başlaması, bir yazıcı sınıfın ve okul geleneğinin oluşmasını sağlamıştır. Bulunan tabletler arasında, yazıcı sınıfın öğrenim aşamasında yaptıkları tekrarları gösteren karalama defterleri türünde olanları mevcuttur. Uruk tabletlerinin bir bölümünde satılan malların listesi, hayvan ve görevli isimlerini içeren listeler de mevcuttu. Bu listeler, başlangıçta tapınaklarda bulunan okullarda uzun yıllar boyunca okuma yazma öğretilirken kopyalanmış ve çoğaltılmıştır (Köroğlu, 2006: 55). Çivi yazısının kullanıldığı diller Sümerce, Akadça, Eblaca, Elamca, Hurice, Hititçe, Urartuca, Ugarit dili ve eski Persçe'dir (Yıldırım, 2004: 68).

Sümerce, günümüzde bilinen hiçbir dille doğrudan akrabalığı kurulamamış bir dildir. Bu bağlamda Sümerlerin kökeni üzerinde çeşitli teoriler üretilmiştir. Kuzeyden, Asya'dan (Çı̆̆, 1994: 685) geldikleri ya da Güney Mezopotamya'nın yerli halk1 olabilecekleri yönündeki görüşler vardır. Sümerce 4000. yılın sonunda ve özellikle de 3000. yılın sonunda yaygın biçimde kullanılmaktaydı. 2000. yılın başında ise resmî işler ve kült törenlerinde kullanılıyordu. Ne zaman ortadan kalktığı konusunda kesin bir bilgiye sahip değiliz. Sümerlerin geliştirdiği yazı sistemi ile birlikte inançları 
konusundaki temel anlatılar, dünya görüşleri, tanrıları ve tapınakları da sonradan gelen toplumlar tarafından benimsenmiştir. Sümerce ilk yazılı belgeler, MÖ 3200 yılına tarihlese de bunların büyük bölümü daha geç tarihlidir. En erken belgeler arasında M.Ö 2800 yıllarına ait Ur tabletleri, M.Ö 2500 yılında yazılmış Fara ve Abu Salabih yazıtları sayılabilir. Erken Sümer Hanedanlar dönemine ait en büyük grup ise Lagaş kentinde ele geçmiştir. Çivi yazısı ve bu yazı ile yazılmış tabletler son yüzyıl içinde okunmuş ve anlaşılmıştır. MÖ 4000. yıldan milada kadar olan bu 3-4 bin yıl gibi uzun bir zamanı kapsayan yeni bir dünyayı önümüze sermiş olmaktadır. Bu zaman diliminde yaşamış olan insanlar hakkında, yine bu insanların kurmuş olduğu büyük imparatorluklar hakkındaki bilgimiz, o dönemin insanlarının bıraktıkları ve toprak altından çıkarılan ve hala çıkarılmakta olan ve yüzyıl öncesine kadar hiç kimsenin okuyamadığı bir yazı ile yani çivi yazısı ile yazılı belgelerin okunmasını ve insanlığın ilgisini bekliyordu. Çivi yazılarının çözülmeye başladığı bu yüzyılda Eskiçağ tarihinin yalnız İncil menkıbelerinden bilinen karanlık devirleri aydınlanmaya başlamıştı (Tosun-Yalvaç, 1989: 1). Sümerlerin geliştirip kullanmaya başladıkları çivi yazısı, insanlık tarihine yaptıkları en önemli katkıdır. Çivi yazısı, kil üzerine, üç köşeli ve ucu sivri bir kalem ile yazılıyordu. Bu yazının önemli başka bir özelliği işaretlerin eşyaları değil düşünce ve heceleri de ifade edebilmesiydi. Çivi yazısı bütün Mezopotamya halkları tarafından kullanılmıştır. Mısır'da ise Roma İmparatorluğu'nun sonuna kadar üç dil kullanılmıştı: Hiyeroglif, Grek, Kopt. Hiyeroglif yazısı IV. yüzyılda, Grekçe VII. yüzyılda sona ermiş Koptça ise Hristiyanların dini bir dili olarak manastırlarda ve kiliselerde XIX. yüzyıla kadar devam etmiştir. Herodotos'un "kutsal yazılar” olarak adlandırdığg hiyeroglifler hakkında Bizans döneminde rahip "Tzetzes”in hiyeroglifli sözlükten kopyalar çıkardığ 1 görülmektedir. 1771 yılında Anquetil du Peron Pehlevice’ye dayanarak Avesta dili ve eski Persçe'yi çözmüştür. Grotefend 1802 yılında Persepolis'te çivi yazılarındaki öz adlarını okumuştur. Mısır yazısını okuyabilmenin başlıca yolu; iki dille yazılmış "bilingue" belgeler ve eski dilin devamı sayılabilecek bir lehçeyi konuşan veya yazan halkın bulunması gerekmektedir. (Köroğlu,2006:30) Eski dille Kopt dilinin bağlantıs1 1643 yılında Kirscher tarafından keşfedilmişti. 1899 yılında Rosette taşı (Reşit taşı) keşfiyle trilingual (üç dilli) bir belge ele geçmişti. Bu MÖ 196 yılında V. Epifan tarafından Mısır tapınaklarına bir ferman gönderilmişti. Bu belgede Grekçe, Hiyeroglif (kutsal yazılar) ve Demotik (halk yazıları) yazıları yer almaktaydı. XIX. yüzyıldan itibaren ise araştırmalar birbirini izlemiş ve XX. yüzyılda eski Mısır tarihi üzerindeki bilgiler birçok yönden artmıştır. 


\section{Sonuç}

Uygarlık tarihinde önemli bir yer tutan ve tarihi devirlere geçişi sağlayan yazı, ilk defa MÖ 4000. yılın sonlarında Mezopotamya'da ortaya çıkmıştır. Yazı, ilk olarak çivi yazısı sistemi ile ve Sümerce olarak başlamıştır. Mağara duvarlarına, kaya ve taşlara yaşadıkları olayları anlatan resimler yapılarak başlanmış ve zamanla bu resimlerin gelişmesiyle ideografik yazı şekli ortaya çıkmıştır. İnsanoğlu kentleri kurmadan önce, MÖ 10.000'li yıllarda Neolitik Dönem ile birlikte ilk kez yerleşik hayata geçmiştir. "Bereketli Hilal” adı verilen Anadolu'nun Güneydoğu Toroslar'ın eteklerinde, ilk köy yerleşimlerinin kurulduğunu görüyoruz. Diyarbakır-Çayönü, Körtik Tepe; Batman-Hallan Çemi; Urfa-Nevali Çöri ve Göbekli Tepe gibi ilk köy yerleşmeleri, insanlığın toprağa yerleştiği ve üretici bir duruma geçtiği bu devirde kurulmuştur. $\mathrm{Bu}$ yerleşmeler, kentlerin ortaya çıkışının öncüleri olmuştur. Orta Anadolu'da MÖ 7000'li y1llarda kurulan Konya-Çatalhöyük ile Kuzey Irak’ta kurulan Jarmo yerleşmeleri de ikincil derece de önemli başka merkezlerdir. Bu iki öncülün ardından ilk kentler, MÖ 4000'li yılların sonlarında Güney Mezopotamya'da ortaya çıkmaya başlamıştır. Sümerler tarafından kurulduğu kabul edilen ilk kentler, aynı zaman da siyasal olarak birer kent devletiydi. Site adı verilen, bu kent devletlerine Ur, Uruk, Eridu, Lagaş, Kiş ve Larsa gibi devletleri örnek verebiliriz. Bilim adamlarının çoğu, ilk gerçek kentlerin MÖ 4750 yılında Sümerler de görüldüğü konusunda hem fikirdir. Mezopotamya'da ortaya çıkan bu gelişme, kısa bir süre sonra benzer bir şekilde Mısır'da da ortaya çıkacaktır. Bu iki bölgede kentlerin benzer bir şekilde ortaya çıkmasında coğrafi olarak Mısır'da Nil Nehri'nin, Mezopotamya'da ise Firat ve Dicle nehirlerinin varlığ1 etkili olmuştur. Ubaid Dönemi ile başlayan kentleşme süreci, Uruk Dönemi'nde gelişme göstermişti. Uruk, gerçek anlamda Mezopotamya'nın ilk kenti denilebilirdi. Akrabalık-aşiret bağlarına dayanan bir toplumdan bölgesel siyasi örgütlenmiş bir topluma geçiş ile kentlerin temelleri, Uruk Dönemi’nde MÖ 4000-3100 atılmaya başlanmıştır. Ur III. Hanedanlığı yıkıldıktan sonra bu bölgeler kendi düzenlerine dönmüşlerdir. Ur, kelime anlamı olarak "kent, şehir” manasında kullanılan bir isimdir. Güneydoğu Anadolu'nun en büyük tarihi kenti olan Harran tufandan sonra yeryüzünde Mezopotamya'nın en büyük ve ünlü kentlerinden biri olan Babil; Irak’ta, Dicle ve Firat nehirleri arasında çok verimli bir sahada Samilerin bir kolu olan Amurrular tarafından kurulmuştur. Tevhid akidesinin merkezi olan Kudüs. Akdeniz ile Kızıldeniz arasında yer alır ve Tel-Aviv'in $40 \mathrm{~km}$ güneydoğusunda kurulmuştur. MÖ 4000'li yıllara kadar uzanan tarihi ile Museviler, Hristiyanlar ve Müslümanlar tarafından kutsal kabul edilen bir şehir olmuştur. Mezopotamya'da hukuk ve kanun 
yazma geleneği Sümerler ile başlamıştır. Bu gelenek ve kanun yazma tekniği zamanla Mezopotamya'da yaşamış olan tüm toplumları etkilemiştir. Urukagina Kanunları, bilinen ilk Sümerce hukuk metnidir. Hammurabi yasaları ise Mezopotamya'da MÖ 1760 yıllarında yazılan tarihin bilinen en eski ve korunmuş yazılı kanunları arasındadır. Bundan başka yazılmış diğer yasa koleksiyonları arasında MÖ 2050 yıllarında yazılmış Ur kralı Ur-Namnu'nun kanun kitabı, MÖ 1930 yıllarında oluşturulan Eşnunna kanun kitabı ve İsin'li Lipit-İștar'ın MÖ 1870 'de hazırlanmış kanun kitabı yer alır. Hiç şüphesiz yazının bulunması uygarlığın, bugün geldiği noktaya ulaşmasında atılmış en önemli adımdır.

\section{Kaynakça}

ATAÖV, Türkkaya (1981). Kudüs ve Devletler Hukuku, Ankara: Yonca Matbaasi.

BAHAR, Hasan (2011). Eskiçağ Uygarlıkları, Konya: Kömen Yayınevi.

BİLGİÇ, Emin (1963).“Eski Mezopotamya Kavimlerinde Kanun Anlayışı ve Ananesi”, Ankara Üniversitesi Dil ve Tarih Coğrafya Fakültesi Dergisi, XXI, 3- 4, 103119.

BUHL, F. (1979). “Kudüs” İstanbul: İslam Ansiklopedisi. Ankara.

CHILLDE, Gordon (1996). Kendini Yaratan Insan, İstanbul: Varlık Yayınları.

CHİLDE, Gordon (2009). Tarihte Neler Oldu, İstanbul: Kırmızı yayınları.

CHİERA, E. (1938). Sie schreiben auf Ton, Leipzig.

ÇIĞ, Muazzez İlmiye (1994). "Sümerlilerden Yahudilik, Hristiyanlık ve Müslümanlığa Ulaşan Etkiler ve Din Kitaplarına Giren Konular” Ankara: Belleten, C. VIII.

DİNÇOL, Belkıs (2003). Eski Önasya Toplumlarında Suç Kavramı ve Ceza, İstanbul: Eskiçağ Bilimleri Enstitüsü.

GÜNALTAY, Şemsettin (1987).Yakın Şark III, Suriye Filistin, Ankara.

GÜNALTAY, Şemsettin (1987). Yakın Şark, Elam ve Mezopotamya, Ankara.

HARMAN, Ömer Faruk (2002). “Kudüs”, İstanbul: Diyanet İslam Ansiklopedisi, C. 26, s. 323-327.

HERZFELD, Ernst (1979). “Babil”, İstanbul: MEB İslam Ansiklopedisi, C 2. 
HIRÇIN, Selen (2000). Çivi Yazısı, İstanbul: Eskiçağ Bilimleri Enstitüsü.

HUOT, Jean-Louis; Thalmann, Jean-Paul; Valbelle, Dominique (2000), Kentlerin Doğuşu, Çev. Ali Bektaş Girgin, Ankara: İmge Kitabevi.

EDWIN, M. Wright (1973). Tale of Two Hamlets, Cleveland, the Northeast Ohio Committee on Middle East Understanding.

ERDEM, Sargon (1991). "Babil”, İstanbul: Diyanet İslam Ansiklopedisi, C. 4.

INAN, Afet (1992). Eski Misir Tarih ve Medeniyeti, Ankara: Türk Tarih Kurumu.

KELEŞ, R. (1992). Kent ve Siyaset Üzerine Yazılar (1975-1992), İstanbul: IulaEmme Yayını.

KINAL, Fürüzan (1963). "Çivi Yazısının Doğuşu ve Gelişmesi”, Ankara: D.T.C.F.D Tarih Bölümü Tarih Araştırmaları Dergisi, Sayı 12.

KOLDOWEY, Robert (1914). Johns Agnes, The Excavations Babylon, London.

KÖROĞLU, Kemalettin (2006). Eski Mezopotamya Tarihi, Başlangıcından Perslere, İstanbul: İletişim Yayınları.

Kudüs (Tarihî Belge) (1988). (Tercüme: Acar Tanlak), Yayınlayan: İslam Konferansı Teşkilatı Kudüs Komitesi, Ankara.

KUHRT, Amelie (2009). Eskiçağda Yakındoğu, Çev. Dilek Şendil, İstanbul: İş Bankası Yayınları.

KRAMER, S. Noah (2002). Sümerler, İstanbul.

MALLOWAN, Max (1964). Noah's Flood Reconsidered, C. XXVI-2, Iraq.

MEMIŞ, Ekrem, (2007). Eskiçağda Mezopotamya, Ankara: Ekin Kitapevi.

M. A. M., (1938). “Jerusalem”, The Jewish Encyclopedia, Newyork.

NISSEN, Hans J. (2004), “Ana Hatlarlyla Mezopotamya”, Çev. Zühre İlkgelen, İstanbul: Arkeoloji ve Sanat Yayınları.

ÖZFIRAT, Aynur (1984). Eskiçağda Harran, İstanbul.

POSGATE, Nicholas (2004). Early Mesopotamia Society and Economy at the Dawn of History, Glasgow.

QUATES, Joan (2004) Babil, Çev. Fatma Çizmeli, Ankara: Arkadaş Yayınevi. 
ROTH, Martha T. (1997). Law Collections from Mesopotamia and Asia Minor, Atlanta, Georgia: Scholars Press.

SARI, Mevlüt (1982). Arapça - Türkçe Lügat, İstanbul.

SEVİN, Veli (2003). Anadolu Arkeolojisi, İstanbul: Der Yayınları.

YARDIMCI, Nurettin (2007). Mezopotamya'ya Açılan Kapı Harran, İstanbul: Ege Yayınları.

YILDIRIM, Recep (2004). Uygarlık Tarihine Giriş, İstanbul.

YILMAZ, Saim (1996)."İslam Tarihinde Kudüs”, İstanbul: Yedi İklim Yayınları, s. 75/76.

TOSUN, Mebrure (1963). "Hammurabi’nin Toprak Kanunları”, Ankara: DTCFD, XXI, 3-4, 127-141.

TOSUN, Mebrure (1973). "Sümer, Babil ve Assurlularda Hukuk, Kanun ve Adalet Kavramları ve Bunlarla İlgili Terimler”, Ankara: Belleten, XXXVII, 145-148, 557-581.

TOSUN, Mebrure Tosun, Yalvaç, Kadriye (1989). Sümer, Babil, Asur Kanunları ve Ammi-Şaduga Fermanı, Ankara: Türk Tarih Kurumu.

Van De Mieroop, Marc (2006). Antik Yakındoğu'nun Tarihi, Ankara: Dost Yayınları.

Van De Mieroop, Marc (2012). Hammurabi, İstanbul: İş Bankası Yayınları.

VERSTEEG, Russ (2000). Early Mesopotamian Law, Durham, North Carolina: Carolina Academic Press.

WOOLLEY, C. Leonard (1929). Ur of the Chaldees. A record of seven years of excavation, London. 


\section{Ekler:}

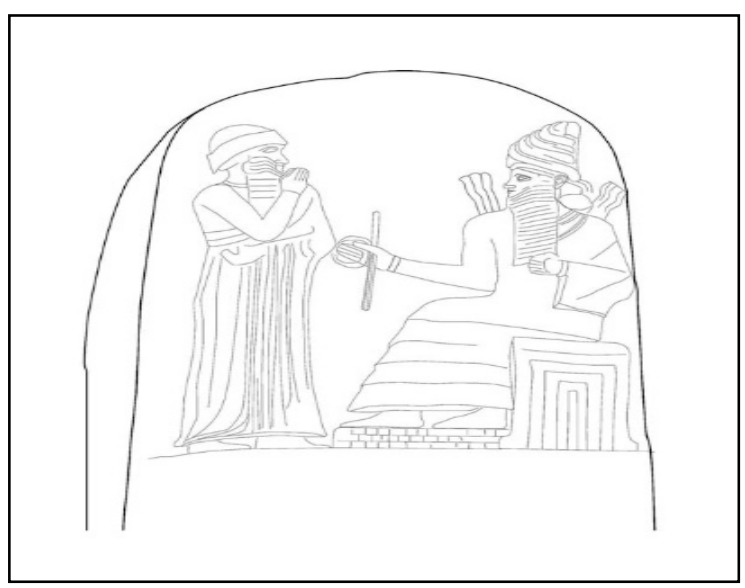

Resim 1 : Hammurabi stelinin üst bölümü. Solda kral Hammurabi,sağda ise Güneş Tanrısı Şamaş, alt bölümde ise kanunları da kapsayanuzun bir yazıt yer alır. (Kaynak: Köroğlu 2010)

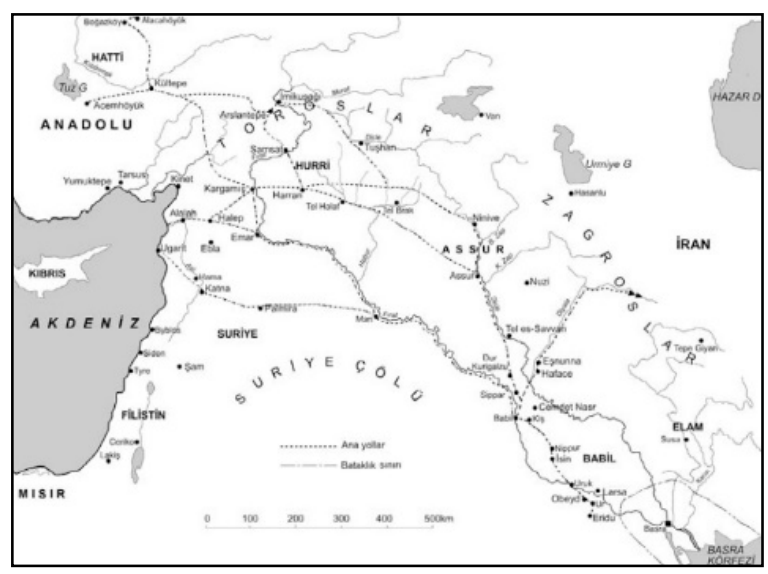

Resim 2: İkinci binyılda Mezopotamya Kaynak: Köroğlu 2010 


\begin{tabular}{|c|c|c|c|c|}
\hline$\sqrt{3}$ & $\mathbb{1}$ & $\varangle$ & $\Leftrightarrow$ & '调件 \\
\hline $\mathbb{D}$ & $D$ & $D$ & t) & Fi \\
\hline 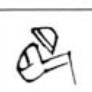 & $\Delta D_{1}$ & $4+7$ & $\Leftrightarrow$ & 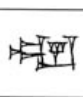 \\
\hline$\beta$ & $\theta$ & $\Leftrightarrow$ & $\infty$ & $\langle F$ \\
\hline 笭 & 文 & 查 & El & $H$ \\
\hline & & & & \\
\hline
\end{tabular}

Resim 3: Başlangıçta resim karakteri taşıyan yazı zaman içinde stilize olarak çivi yazısı biçimine dönüşmüştür. Kaynak: Postgate 1992

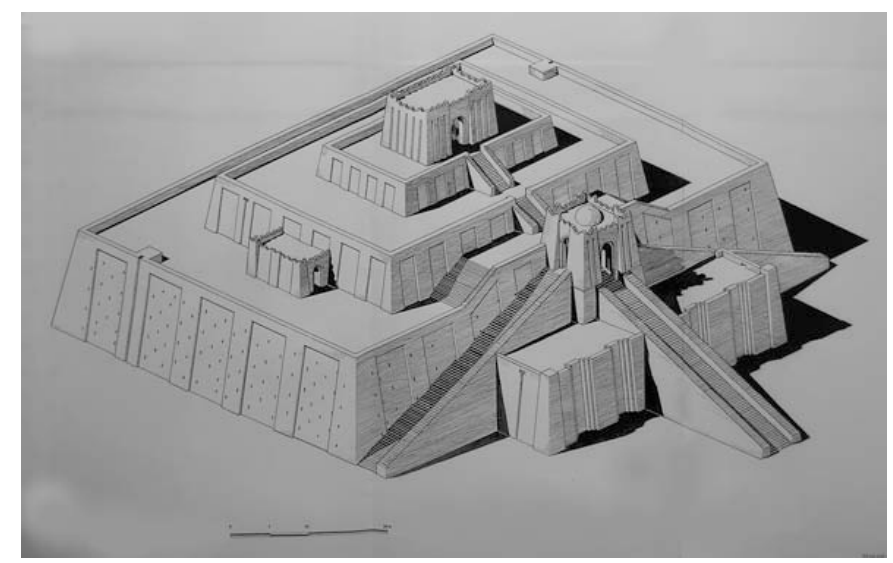

Resim 4: Ur Zigguratı'nın kentteki kazıları yürüten Woolley tarafından yapılan rekonstrüksiyonu. Kademeli bir biçimde yükselen zigguratın tepesinde bir tapınak yer almaktadır Kaynak: Wooley 1939 


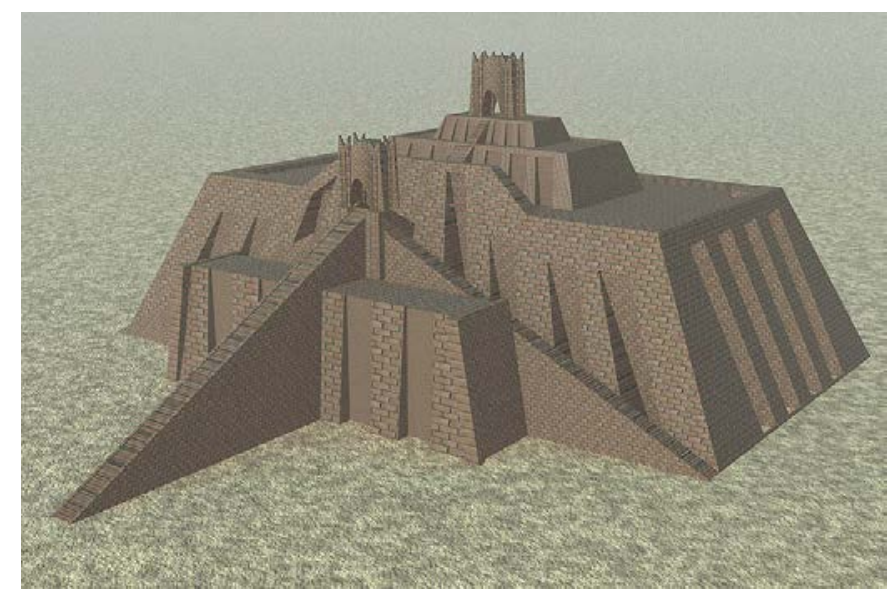

Resim 5: Ziggurat of Ur-Own work, based on a 1939 drawing by Leonard Woolley, Ur Excavations, Volume V. The Ziggurat and its Surroundings, Figure 1.

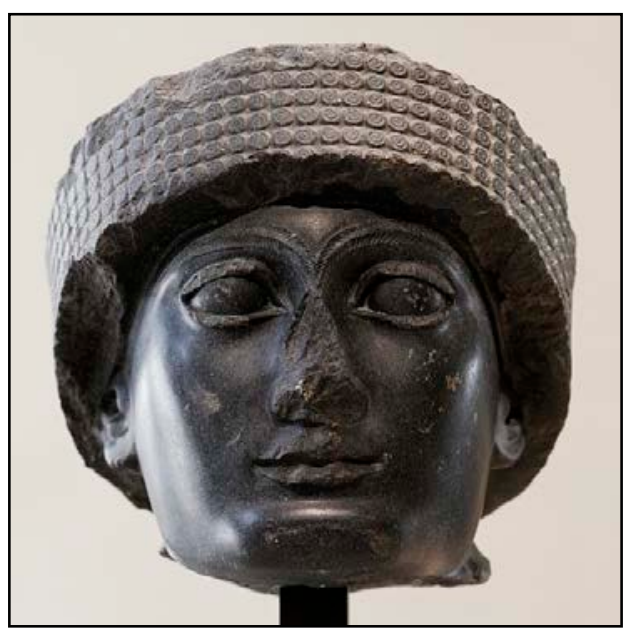

Resim 6: Lagaş Kralı Gudea...Musée du Louvre, Atlas database

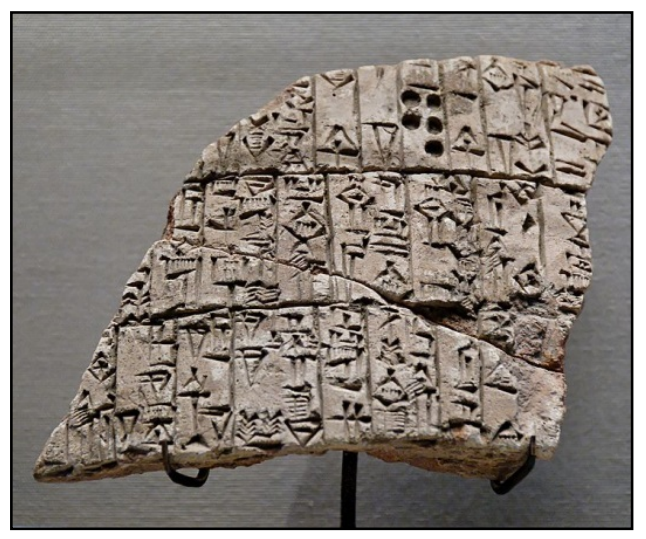


Resim 7: Urukagina Kanunnamesi

Mésopotamie, room 1a: La Mésopotamie du Néolithique à l'époque des Dynasties archaïques de Sumer. Richelieu, ground floor. This work is part of the collections of the Louvre (Department of Near Eastern Antiquities). 